\title{
Comparative analysis of cases of measles from Romania, Bulgaria and Hungary in the context of the European Union
}

\section{Analiza comparativă a cazurilor de rujeolă din România, Bulgaria şi Ungaria în contextul Uniunii Europene}

Ana Maria Alexandra STĂNESCU ${ }^{1}$, Alexandra TOTAN ${ }^{3}$, Daniela MIRICESCU ${ }^{3}$, Constantin ŞTEFANI ${ }^{1}$, Bogdan ŞERBAN ${ }^{1}$, Ioana Veronica GRĂJDEANU ${ }^{1}$, Camelia Cristina DIACONU ${ }^{1,2}$

${ }^{1}$ Universitatea de Medicină şi Farmacie „Carol Davila“, Bucureşti, România

${ }^{2}$ Spitalul Clinic de Urgenţă, Bucureşti, România

${ }^{3}$ Departamentul de Biochimie, Facultatea de Medicină Dentară, Universitatea de Medicină şi Farmacie „Carol Davila“, Bucureşti, România

\section{ABSTRACT}

Expansion of measles cases is an alarm signal in Romania, with most of the European Union in our country. There is a clear need for higher rates of vaccination of the population. Romania ranks first in Europe in terms of measles deaths as well as cases of measles exported to other EU countries. Neighboring countries such as Bulgaria and Hungary succeed to have a much better management of measles.
\end{abstract}

Keywords: measles, Romania, Bulgaria, Hungary, vaccination

\section{REZUMAT}

Extinderea cazurilor de rujeolă reprezintă un semnal de alarmă pe teritoriul României, țara noastră având cele mai multe din Uniunea Europeană. Este evidentă necesitatea unei rate mai mari de vaccinare a populației. România este pe primul loc în Europa şi în ceea ce priveşte decesele datorate rujeolei, dar şi în privința cazurilor de rujeolă exportate către alte țări din Uniunea Europeană. Țările vecine, precum Bulgaria şi Ungaria, reuşesc să aibă un management mult mai bun în ceea ce priveşte rujeola.

Cuvinte cheie: rujeolă, România, Bulgaria, Ungaria, vaccinare

\section{INTRODUCERE}

Rujeola este o boală virală extrem de infecţioasă, asociată cu febră şi erupţie cutanată. Cei mai afectaţi sunt copiii. Rujeola poate avea complicaţii grave, inclusiv pneumonia şi encefalita, putând duce la deces (1).
Epidemia de rujeolă este încă prezentă nu numai în ţările subdezvoltate, ci şi în ţările în curs de dezvoltare. În Statele Unite, începând din 1963, cazurile de rujeolă au suferit un declin (de la 500.000 cazuri la $<1.500$ cazuri pe an), această scădere fiind datorată unei rate mari de vaccinare, rezultând în eliminarea transmiterii endemice în anul 2000 (2). 
Au fost observate cazuri la care, din punct de vedere genetic, virusul izolat a diferit de virusul vaccinului, ceea ce influenţează negativ ţelul de a elimina rujeola (3). Virusul rujeolic este serologic monotipic, dar genotiparea confirmă opt clase (A$\mathrm{H})$; alelele sunt subdivizate în 23 de genotipuri, iar numărul este posibil să crească pe măsură ce mai multe zone geografice vor fi cercetate (4). Vaccinul în uz curent este preparat din clasa $A$, iar nivelul de protecţie oferit de acest vaccin variază de la genotip la genotip (5).

În timpul epidemiei de rujeolă, copiii care prezintă febră şi erupţie cutanată nu sunt, de obicei, supuşi evaluării de laborator; la pacienţii aparţinând altor grupe de vârstă, care prezintă febră şi erupţie cutanată, diagnosticul agentului cauzal depinde în mare măsură de investigaţiile de laborator $(6,7)$.

\section{OBIECTIVE}

- Determinarea prevalenţei rujeolei în România comparativ cu ţările vecine: Bulgaria şi Ungaria.

- Identificarea posibilităţilor de reducere a numărului de cazuri de rujeolă pe teritoriul României.

\section{MATERIAL ŞI METODĂ}

Utilizând datele raportate de către Centrul European de Prevenţie şi Control al Bolilor (8), din raportul ţărilor din UE cu risc de a dezvolta rujeolă (ianuarie 2016 - martie 2019), am analizat comparativ România, Bulgaria şi Ungaria. Prin această comparaţie, s-a urmărit evidenţierea României în ceea ce priveşte prezenţa rujeolei comparativ cu ţările vecine Bulgaria şi Ungaria. Datele au fost introduse în Microsoft Excel, unde au fost prelucrate şi analizate statistic.

\section{REZULTATE}

România a raportat în perioada ianuarie 2016 - martie 201917.850 de cazuri de rujeolă, dintre care 7.370 au fost confirmate. Acest număr de cazuri este raportat la numărul total de locuitori, de 19.530.631. Bulgaria a raportat 415 cazuri de rujeolă, 345 fiind confirmate, la un număr total de locuitori de 7.050.034. Bulgaria are numai 4,5\% din totalul cazurilor declarate de România şi Bulgaria, în timp ce România deçine 95,5\%. În Ungaria, la o populaţie totală de 9.778 .371 de locuitori, au fost raportate numai 61 de cazuri confirmate.

Decesele datorate rujeolei în România au fost în număr de 59, în timp ce în Bulgaria a fost înregistrat un singur deces. România are numărul cel mai mare de decese datorate rujeolei din UE (numărul total de decese datorită rujeolei în UE - 84), în timp ce Ungaria nu a înregistrat niciun deces.

La nivelul UE sunt în medie 26,1 cazuri de rujeolă la 1 milion de locuitori. România are rata cea mai mare, de 283,4 cazuri la 1 milion de locuitori.

Atât în România, cât şi în Bulgaria, cei mai afectaţi de această boală sunt copiii.

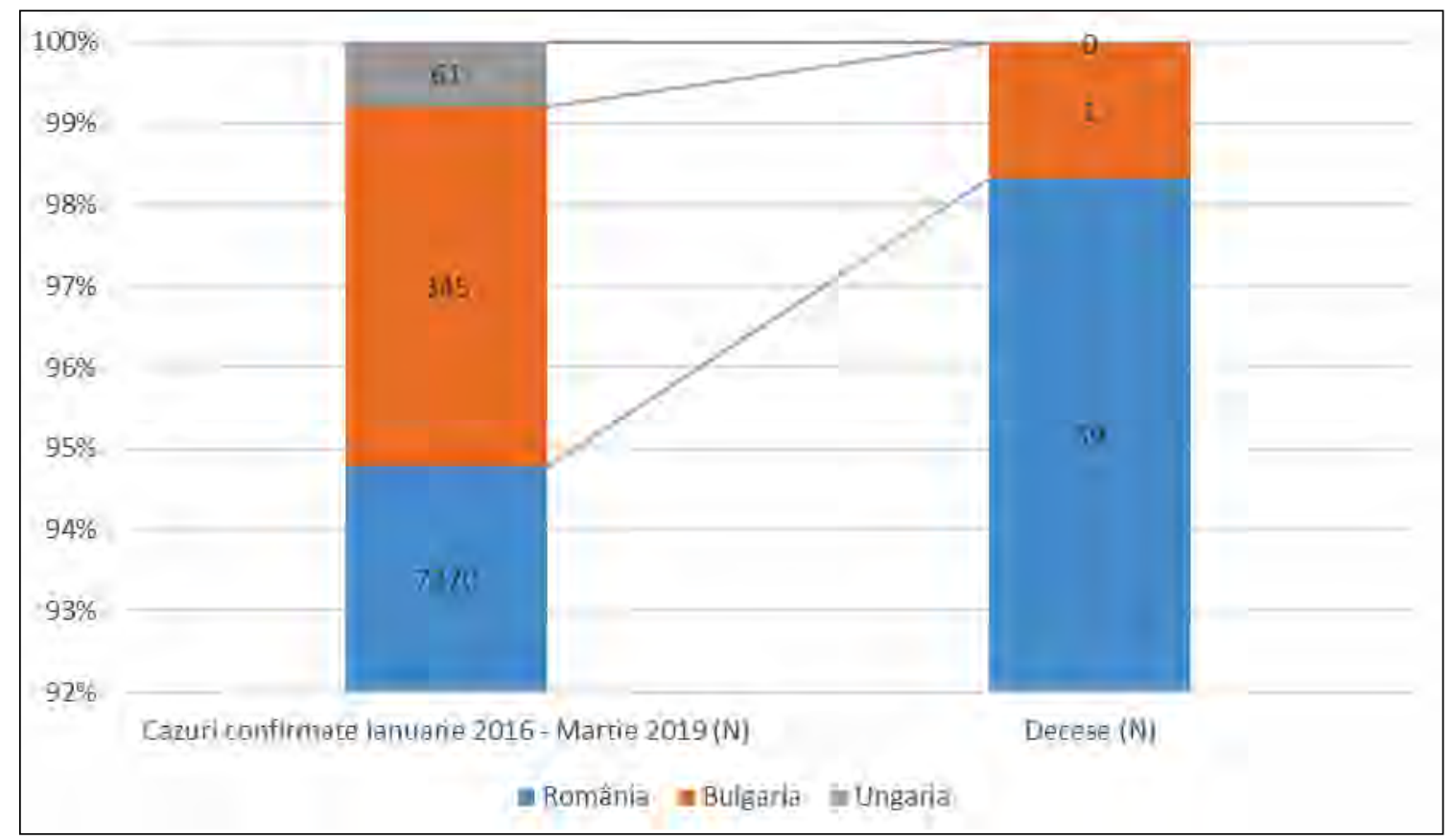

FIGURA 1. Reprezentarea grafică a cazurilor confirmate şi a deceselor în România, Bulgaria şi Ungaria 


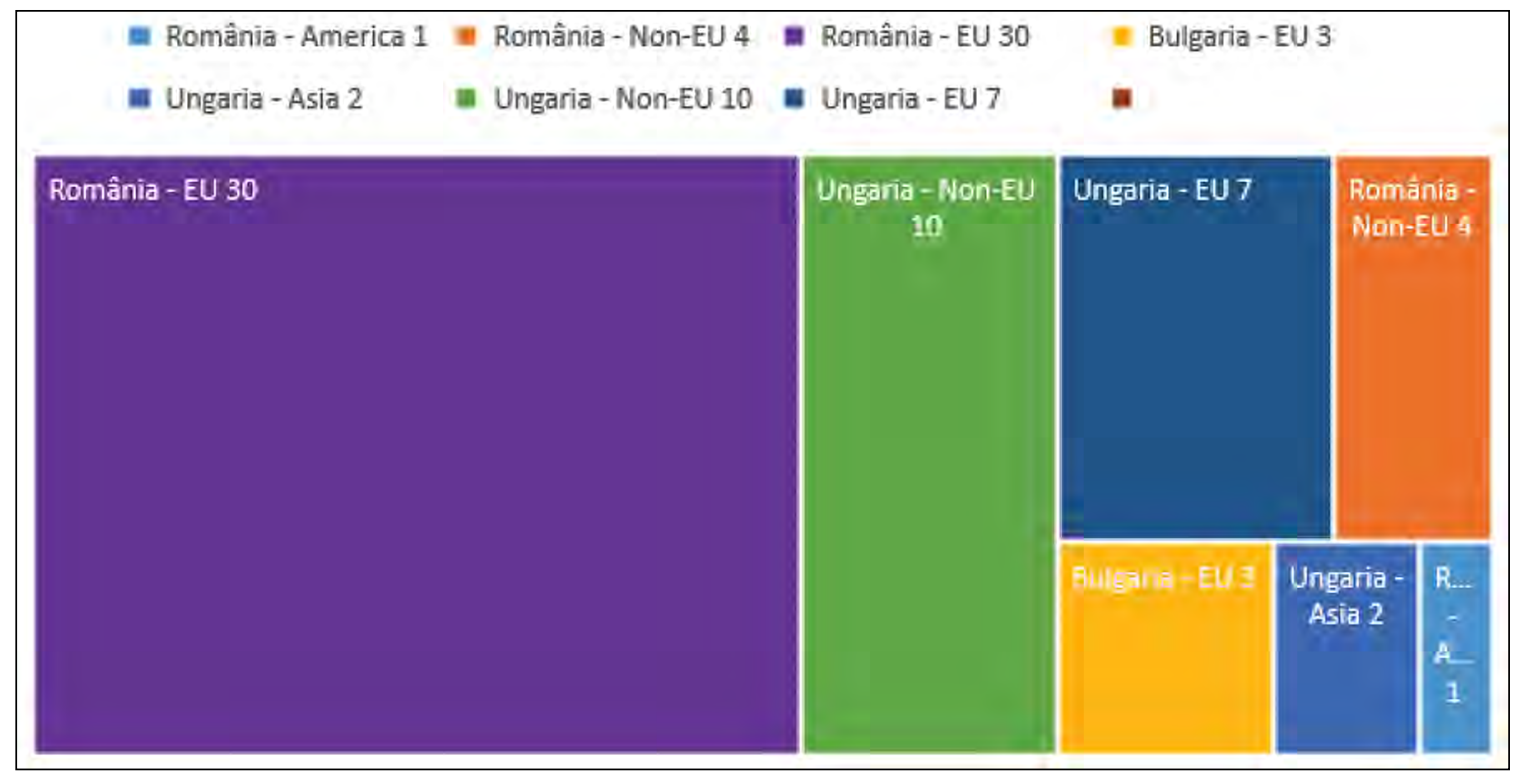

FIGURA 2. Provenienţa probabilă a cazurilor importate

Schema de vaccinare poate fi diferită de la o ţară la alta. În România, vaccinarea se face la vârsta de 12 luni şi la 5 ani, în timp ce în Bulgaria vaccinarea se face la 13 luni şi la 12 ani, iar în Ungaria la 15 luni şi la 11-12 ani.

TABELUL 1. Schema de vaccinare antirujeolă

\begin{tabular}{|c|c|c|}
\hline Ṭara & $\begin{array}{c}\text { Vârsta la care se } \\
\text { administrează doza I }\end{array}$ & $\begin{array}{c}\text { Vârsta la care se } \\
\text { administrează doza II }\end{array}$ \\
\hline România & 12 luni & 5 ani \\
\hline Bulgaria & 13 luni & 12 ani \\
\hline Ungaria & 15 luni & $11-12$ ani \\
\hline
\end{tabular}

S-a estimat că 94.705 persoane reprezintă populaţia nevaccinată din România cu vârsta cuprinsă între 0 ani şi 20 ani, iar din totalul naşterilor 2,3\% nu sunt vaccinaţi. În Bulgaria, 58.515 nu sunt vaccinaţi, iar în Ungaria - 18.492.

TABELUL 2. Reprezentare generală comparativă între România, Bulgaria şi EU

\begin{tabular}{|c|c|c|c|c|c|}
\hline Țara & $\begin{array}{c}\text { Cazuri } \\
\text { (N) }\end{array}$ & $\begin{array}{c}\text { Vârsta } \\
\text { medie } \\
\text { (ani) }\end{array}$ & $\begin{array}{c}\text { Decese } \\
\text { (N) }\end{array}$ & $\begin{array}{c}\text { Cazuri } \\
\text { importate } \\
\text { (N) }\end{array}$ & $\begin{array}{c}\text { Cazuri } \\
\text { exportate } \\
\text { către EU (N) }\end{array}$ \\
\hline România & 17.850 & $4(1-10)$ & 59 & 53 & 253 \\
\hline Bulgaria & 415 & $4(1-14)$ & 1 & 9 & 5 \\
\hline Ungaria & 61 & $29(3-40)$ & 0 & 19 & 5 \\
\hline EU & 44.074 & $10(2-27)$ & 84 & 1.599 & 0 \\
\hline
\end{tabular}

\section{DISCUȚII}

Deşi există un vaccin eficient, rujeola rămâne o cauză majoră a morbidităţii şi mortalităţii copiilor în multe părţi ale lumii. În 2015, mai mult de 134.000 de decese legate de rujeolă au avut loc la nivel global (9). România are cele mai multe cazuri de rujeolă din Uniunea Europeană în prima parte a anului 2019, ţările vecine având mult mai puţine cazuri, în special Ungaria.

Riscul de deces datorat rujeolei între anii 1980 şi 2008 a variat de la 0 la 0,40, cu o medie de 0,0391 (10). România are cele mai multe decese din cauza rujeolei din UE, Bulgaria are raportat 1 deces, iar în Ungaria nu există cazuri de deces. A fost sugerat că la baza deceselor în copilărie cauzate de bolile infecţioase ar sta malnutriţia (mai ales în ţările subdezvoltate şi în curs de dezvoltare) (11). Această sugestie a fost confirmată de unele studii şi infirmată de altele, cu toate acestea, este dificil de estimat starea nutriţiei înainte de infectare $(11,12,13)$.

Se consideră eliminat statutul endemic de rujeolă atâta timp cât virusul rujeolic nu stabileşte un lanţ de transmisie care să se întindă $>12$ luni într-o regiune (14). România face parte din puţinele ţări (10 la nivel mondial, dintre care 5 în Europa) care încă mai au epidemie de rujeolă, în schimb, Bulgaria şi Ungaria au eliminat epidemia de rujeolă. În acest context, cercetarea de laborator, inclusiv identificarea şi genotiparea virusului, este critică; analiza epidemiologică moleculară poate furniza informaţii despre modelele de transmitere a tulpinilor de virus circulant şi poate ajuta la identificarea potenţialelor surse de infecţie (14).

Un alt punct de vedere important este reprezentat de importul şi exportul cazurilor de rujeolă. România reprezintă un pericol din punct de vedere al exportului rujeolei, având 253 de cazuri exportate până în martie 2019. Bulgaria şi Ungaria au exportat câte 5 cazuri fiecare. 
Administrarea a două doze de vaccin împotriva rujeolei reprezintă cea mai eficientă metodă de prevenire a bolii. Rata ridicată a vaccinării în două doze de $>95 \%$ este metoda care contribuie la eliminarea rujeolei $(15,16,17)$. Atât România, cât şi Bulgaria au o rată a vaccinării sub $95 \%$, în timp ce Ungaria menţine rata de vaccinare peste $95 \%$.

\section{CONCLUZII}

Este posibilă eliminarea rujeolei în România prin creşterea numărului de persoane vaccinate, iar menţinerea acestui statut se poate obţine prin continuitate în ceea ce priveşte vaccinarea. Pentru eliminarea definitivă, pentru prevenirea eşecurilor vaccinării, dar şi pentru o protecţie sporită, sunt necesare o cercetare mai amănunţită şi crearea unui vaccin alternativ.
Conflict of interest: none declared Financial support: none declared

\section{$\overline{\text { BIBLIOGRAFIE }}$}

1. Strebel PM, Papania MJ, Dayan GH et al. In: Plotkin SA, Orenstein WA, Offit PA, editors. Vaccines. 5th ed. Philadelphia, PA: WB Saunders; 2008. p. 358.

2. Blumberg S, Enanoria WT, Lloyd-Smith JO et al. Identifying postelimination trends for the introduction and transmissibility of measles in the United States. Am J Epidemiol 2014;179:1375-82

3. Bellini WJ, Rota PA. Genetic diversity of wild-type measles viruses: Implications for global measles elimination programs. Emerg Infect Dis 1998;4:29-35.

4. Riddell MA, Rota JS, Rota PA. Review of the temporal and geographical distribution of measles virus genotypes in the prevaccine and postvaccine eras. Virol $J$ 2005;2:87

5. Klingele M, Hartter HK, Adu F et al. Resistance of recent measles virus wild-type isolates to antibody-mediated neutralization by vaccinees with antibody. J Med Virol 2000;62:91-8

6. Coleman KP, Markey PG. Measles transmission in immunized and partially immunized air travellers. Epidemiol Infect 2010;138:1012-5.
7. Stefani C, Grajdeanu IV, Serban B et al. Abordarea depresiei în practica medicului de familie. Revista Medicală Română 2019;LXVI(1):24-28.

8. European Centre for Disease Prevention and Control. Who is at risk for measles in the EU/EEA? Identifying susceptible groups to close immunity gaps towards measles elimination. Stockholm: ECDC; 2019.

9. World Health Organization. WHO Measles Fact Sheet. 2016. Available: http://www. who.int/mediacentre/factsheets/fs286/en/

10. Wolfson LJ, Grais RF, Luquero FJ et al. Estimates of measles case fatality ratios: A comprehensive review of community-based studies. International Journal of Epidemiology. 2009;38(1):192-205

11. Rice AL, Sacco L, Hyder A et al. Malnutrition as an underlying cause of childhood deaths associated with infectious diseases in developing countries. Bulletin of the World Health Organization. 2000;78(10):1207-1221.

12. Aaby P. Malnutrition and overcrowding/ intensive exposure in severe measles infection: review of community studies. Clinical Infectious Diseases. 1988;10(2):478-491.
13. Mahamud A, Burton A, Hassan M et al. Risk factors for measles mortality among hospitalized Somali refugees displaced by famine, Kenya, 2011. Clinical Infectious Diseases. 2013;57(8):e160-e166.

14. Pan American Health Organization. Plan of action documentation and verification of measles, rubella, and congenital rubella syndrome elimination in the Region of theAmericas. http://www.paho.org/hq/index. php?option=com_docman\&task $=$ doc_ download\&gid $=16739$ \&ltemid $=270$

15. Grajdeanu IV, Stănescu AMA, Stefani $C$ et al. Impactul asupra mamei, fătului şi nou-născutului în cazul varicelei la gravidă. Practica Medicală 2019;14,1(64):21-25.

16. lancu MA, Bejan CG, Baltă MD et al. Principii generale de recuperare a vaccinării restante a copiilor. Revista Medicală Română 2018;LXV(2):112-115.

17. van Boven $M$, Kretzschmar M, Wallinga J et al. Estimation of measles vaccine efficacy and critical vaccination coverage in a highly vaccinated population. $J R$ Soc Interface. 2010;7:1537-44. 